\title{
HYDROLYSE DES TRIGLYCÉRIDES A CHAINES LONGUES DANS LA GAILLETTE DU VEAU PRÉRUMINANT
}

\author{
R. TOULLEC et L. FELINSKI ( $\left.{ }^{(}\right)$
}

Station de Recherches sur l'Élevage des Ruminants, Centre de Recherches de Clermont-Ferrand, I. N. R. A., 63 - Saint-Genès-Champanelle

Trois veaux préruminants ont été munis d'une canule de la caillette et de 2 canules d'ASH placées immédiatement après le pylore. Ils ont reçu des laits de remplacement ne contenant que du suif (22 à $25 \mathrm{P}$. Ioo de la matière sèche) comme source de matières grasses ou du lait écrémé additionné d'amidon. Les canules du duodénum étaient déconnectées et la caillette vidée et rincée avant les repas expérimentaux, pour éliminer le suc pancréatique qui aurait pu refluer. Les prélèvements au niveau du duodénum duraient I 2 heures consécutives avec réintroduction simultanée. Lorsque les animaux ont reçu le régime riche en lipides (57 échantillons obtenus en 7 journées de prélèvement), nous avons toujours observé une forte proportion d'acides gras libres dans. les lipides sortant de la caillette ( $24 \mathrm{p}$. Ioo en moyenne avec des extrêmes de 6 et 42 ). Cela provenait probablement d'une hydrolyse des triglycérides alimentaires dans la caillette. En effet, en régime lipidoprive, les quantités de lipides sécrétées dans la caillette étaient très faibles ( $\mathrm{p}$ p. Ioo de la matière sèche). De plus, les lipides sortant de la caillette étaient très riches en phospholipides. ( 37 p. roo en moyenne) en régime lipidoprive alors qu'ils en étaient pratiquement dépourvus en régime riche en lipides. En outre, ils contenaient des proportions plus élevées d'acide linoléique que les fractions correspondantes après ingestion des régimes riches en lipides.

Il semble donc y avoir chez le Veau préruminant une " lipase " capable d'hydrolyser les triglycérides à chaînes longues au niveau de la caillette. Cette lipase est différente de l'estérase prégastrique puisque, in vitro, Grosskopf (1965) a montré que cette dernière n'agit que sur les triglycérides contenant de l'acide butyrique en libérant uniquement ce dernier acide. L'action de cette lipase est loin d'être négligeable car les quantités d'acides gras qu'elle libère correspondent à environ $50 \mathrm{p}$. 100 des quantités qui sont probablement libérées par la lipase pancréatique. Cette lipase ne semble pas avoir de spécificité intramoléculaire, contrairement à la lipase pancréatique, puisque les glycérides partiels formés ont une composition en acides gras très proche de celle des triglycérides des aliments (tabl. I). Il reste cependant à préciser le mode d'action et le lieu de sécrétion de cette enzyme.

\section{SUMMARY}

\section{HYDROLYSIS OF LONG CHAIN TRIGLYCERIDES IN THE ABOMASUM OF THE PRERUMINANT CALF}

Three preruminant calves were fitted with an abomasum cannula and 2 ASH cannulae placed immediately after the pylorus. They received either milk substitutes containing only tallow (22 to $25 \mathrm{p}$. Ioo of the dry matter) as a source of fat, or starch-enriched skim-milk. The

(r) Wyzska Szkola Rolnicza Dziekanat Wydzialu Zootechnicznego ul. Janosika 8 Szczecin (Pologne). 


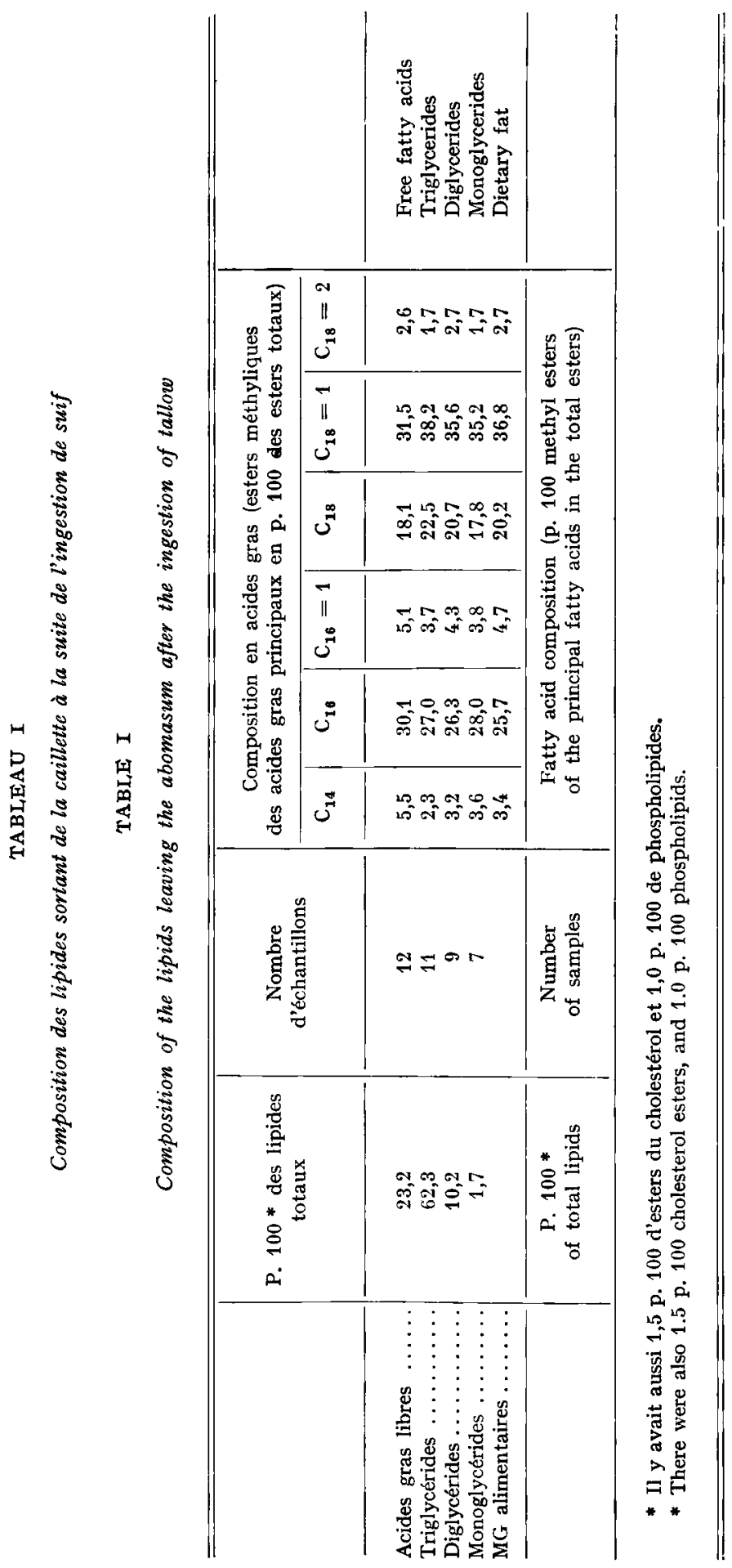


duodenum cannulae were disconnected, and the abomasum emptied and rinsed before the experimental meals, in order to eliminate any pancreatic juice which might flow back. Samples were taken from the duodenum for 12 consecutive hours, accompanied by a simultaneous reintroduction of the contents. When the animals were fed a lipid-rich diet ( 57 samples taken during 7 sampling days), a high proportion of free fatty acids leaving the abomasum was always observed (24 p. roo on the average, the extreme values being 6 and 42 ). This was probably due to a hydrolysis of the dietary triglycerides in the abomasum. In fact, when the animals were fed a lipid free diet, the amount of lipids released in the abomasum was very low (I p. Ioo of the dry matter). Moreover, these lipids were very rich in phospholipids ( $37 \mathrm{p}$. Ioo on the average) while, on the lipid-rich diet, there were practically no phospholipids present. In addition, they contained higher proportions of linoleic acid than the corresponding fractions obtained after the ingestion of the lipid-rich diets.

It therefore seems that in the preruminant calf, there is a "lipase " capable of hydrolyzing long chain triglycerides in the abomasum. This lipase differs from the pregastric esterase, because GROSSKOPF ( 1965 ) has shown that, in vitro, the latter enzyme only acts on triglycerides containing butyric acid, liberating this acid only. This lipase is quite active because the amount of fatty acids it liberates, corresponds approximately to $5^{\circ} \mathrm{p}$. I 100 of that probably released by pancreatic lipase. In contrast to pancreatic lipase, this other lipase does not seem to have an intramolecular specificity, since the partial glycerides formed have a very similar fatty acid composition to that of the dietary triglycerides (table 1 ). The mode of action and the site of secretion of this enzyme remain to be described.

\title{
RÉFÉRENCE BIBLIOGRAPHIQUE
}

Grosskopf J. F. W., I965. Studies on salivary lipase in young ruminants. Onderstepoort J. Vet. Res. 32, I53-180.

\section{UTILISATION DIGESTIVE DU CALCIUM GHEZ LE PORC ET LE LAPIN QUELQUES FACTEURS DE VARIATION}

\author{
P. BESANÇON et L. GUÉGUEN \\ Station de Recherches de Nutrition, \\ Centre national de Recherches zootechniques, I. N. R. A., \\ 78 - Jouy-en-Josas
}

On sait, à la suite des travaux de nombreux auteurs, que le niveau d'ingestion calcique a une grande influence sur l'absorption du calcium. Par ailleurs, la rétention et le renouvellement du calcium osseux sont fonction du calcium absorbé, donc de l'apport exogène de $\mathrm{Ca}$. Chez le Porc en croissance, en augmentant les niveaux d'apport calcique de 8 à $17 \mathrm{~g} / \mathrm{kg}$ d'aliment, on diminue le CUDr ${ }^{(1)}$ de 45 à 38 p. Ioo; cependant, la rétention calcique est augmentée : en effet, la mobilisation du calcium osseux est alors 4 fois plus faible, tandis que l'anabolisme osseux n'est que légèrement accru. Chez le Lapin en croissance, les CUDr sont toujours beaucoup plus élevés 